\title{
BIOGAS PRODUCTION FROM TOFU LIQUID WASTE ON TREATED AGRICULTURAL WASTES
}

\author{
${ }^{1}$ Budy Rahmat, ${ }^{2}$ Tedi Hartoyo and ${ }^{1}$ Yaya Sunarya \\ ${ }^{1}$ Department of Agrotechnology, \\ ${ }^{2}$ Department of Agribussines, \\ Faculty of Agriculture, Siliwangi University, Tasikmalaya, Indonesia
}

Received 2014-01-10; Revised 2014-01-18; Accepted 2014-02-01

\begin{abstract}
The Tofu Liquid Waste (TLW) as a pollution might be processed into biogas which was environmentally friendly and had potential to replace burning wood or oil. However, the waste could not directly be employed as the biogas substrate due to the high nitrogen content which was not suitable to the methanogen microorganism on the biogas digester and did not produce biogas. It was therefore necessary to adapt the carbon-nitrogen ratio in TLW with the addition of other organic materials that had a lower nitrogen content so it would be a suitable substrate for generating biogas. The research was aimed to evaluate the addition of the other organic material on the TLW to increase the biogas production. The results showed that TLW combined with sheep dung, cabbage waste, bamboo leaves and paddy straw respectively produced biogas as much as $14,183,7,250,2,400,895 \mathrm{~cm}^{3}$ in 20 days. The 4 treatments gave the same quality of biogas, which was determined using the water boiling test. The $\mathrm{pH}$ fluctuation during the process was in the right $\mathrm{pH}$ for anaerobic digestion, thus it was not the limiting factor.
\end{abstract}

Keywords: Agricultural Wastes, Biogas Production, Tofu Liquid Waste, Treatment

\section{INTRODUCTION}

Tofu Liquid Waste (TLW) is produced from the production of tofu. The TLW came from the immersing water, the tofu water which does not clot, the chunk of tofu. The TLW is turbid and light yellow into white. In anaerobic condition, it will turn into black and stinky upon standing due to the degradation of protein and carbohydrate (Astuti et al., 2007).

The industry of tofu has a potential to contaminate the environment due to the large amount of the produced waste. The waste might give the environmental problems such as the stinky smell and water pollution. Due to the negative impacts, the development of the industry is resisted by the society surrounding. Therefore, the tofu industry should be developed to be more environmentally friendly which focuses on two main aspects of the conservation of resources and the minimization of the negative impacts on the environments (Husni and Esmiralda, 2012).

\section{Corresponding Author: Budy Rahmat, Department of Agrotechnology Faculty of Agriculture, Siliwangi University, Tasikmalaya, Indonesia}

The tofu industry might be classified into small scale industry, thus the waste treatment needed should be simple, low operational cost and high economical value. The anaerobic digester which decays the TLW into biogas is considered to be qualified with such requirements. Beside producing the odorless liquid, the produced biogas might replace the wood or the oil employed in the processing of the soybean into tofu.

The remaining liquid waste still has the organic content which might be utilized for the alternative energy. The anaerobic degradation is the natural process which might digest the organic matter. The anaerobic process is conducted in the close system on a certain time depend on the character of biomass. Innovation on the digester design which is suitable to the decay time is needed to obtain the optimum results (Goendi et al., 2008). Such opportunity has not been optimally utilized as the TLW could not be directly employed as the biogas substrate by considering the high nitrogen content. Novita (2009) reported that the TLW had the 
ratio $\mathrm{C} / \mathrm{N}$ of 5.19 , where the required ratio was between 20-30 (Burke, 2001; Kaswinarni, 2007).

This study presented the results of biogas production of the TLW and compared the produced biogas from TLW and other agricultural wastes.

\section{MATERIALS AND METHODS}

\subsection{Raw Material and Preparation of Slurry}

The TLW as the biogas substrate was obtained from four home industries on the center of tofu industry on Indihiang. As much as $100 \mathrm{~L}$ of waste was taken, homogenized, mixed and stirred. The paddy straw and bamboo leaves were obtained from various locations on the subdistrict of Tawang. The cabbage waste was collected from Cilembang Market Center in Tasikmalaya. The organic material $(2.5 \mathrm{~kg})$ was cut into the size of $1 \mathrm{~cm}^{2}$ before being mixed with $50 \mathrm{~L}$ of TLW.

\subsection{Experimental Setup}

The study was conducted to examine the treatments of: (A) TLW as the control; (B) TLW+sheep dung; (C) TLW+rice straw; (D) TLW+bamboo leave waste; (E) TLW+cabbage waste. The treatments were arranged in randomized experimental designs. The data were analyzed by using analysis of variance (Anova) and continued with the Duncan's multiple different test (Gomez and Gomez, 1984).

\subsection{Fabrication of Digesters}

Each digester (Fig. 1) was made of $60 \mathrm{~L}$ of metal drum as the digester vessel. On the vessel, there were: (i) substrate inlet pipe with the diameter of $8 \mathrm{~cm}$ installed with the angle of $30^{\circ}$ toward vertical wall on the height of $15 \mathrm{~cm}$ from the bottom of vessel; (ii) residue output pipe with the diameter of $8 \mathrm{~cm}$ with the angle of $45^{\circ}$ toward vertical wall on the height of $25 \mathrm{~cm}$ from the bottom of vessel; (iii) gas sealed stirrer shaft on the center of cylinder with two stirrer installed at 13 and $40 \mathrm{~cm}$ from the bottom of vessel and (iv) biogas output pipe with the diameter of $0.8 \mathrm{~cm}$ connected with the gas volume meter installation. All the connection were conducted with metal welding to avoid the gas leak.

\subsection{Monitoring Parameters}

Response variables due to the treatments were daily biogas production, total biogas production in 20 days, fluctuation of substrate $\mathrm{pH}$ and the quality of biogas combustion. The digester was connected with the reversed measuring flask $\left(1.000 \mathrm{~cm}^{3}\right)$ with the assumption that the moved water was equal with the volume of biogas. The volume of produced biogas on the each digester was separately recorded. The $\mathrm{pH}$ was determined using $\mathrm{pH}$-meter. The water boiling test was performed using Bunsen lamp, where the glass was filled with the distilled water, statif and hand thermometer.

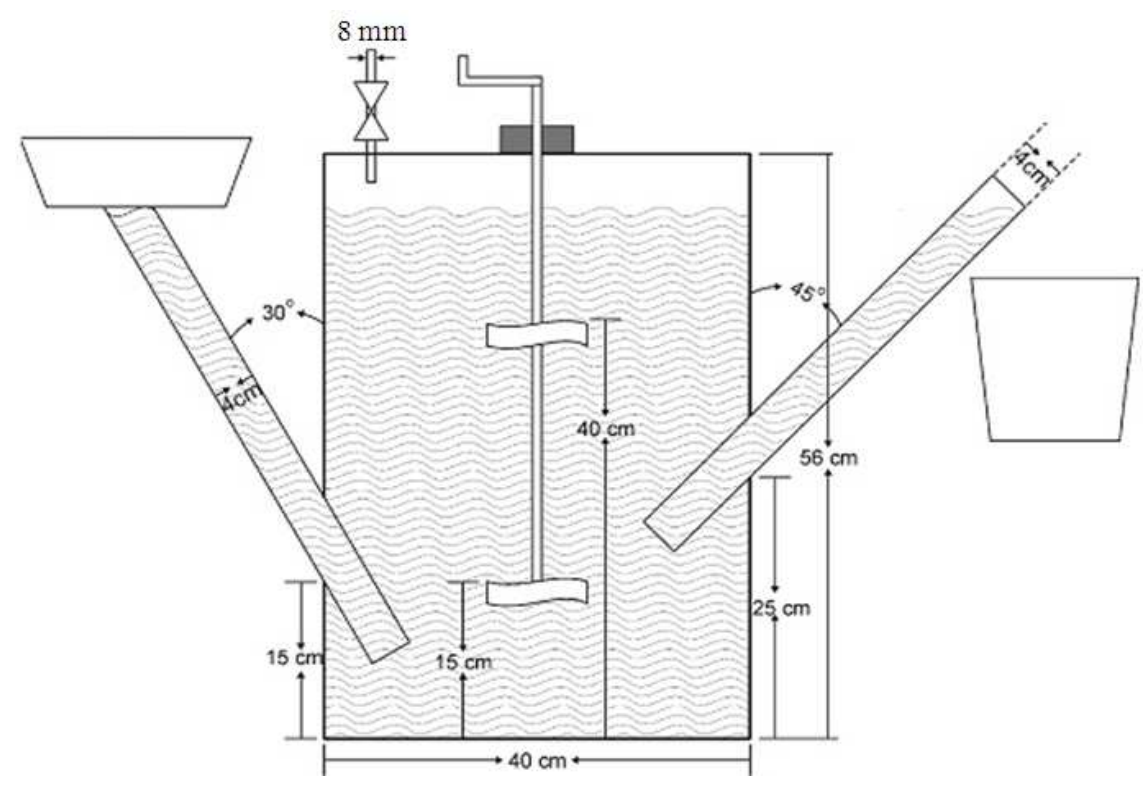

Fig. 1. Fixed Dome Biogas Digester: (1) substrate filling funnel; (2) inlet pipe; (3) pipeline and valve biogas diverter; (4) stirrer; (5) residual outlet pipe; (6) substrate digester; (7) residue for fertilizer 


\section{RESULTS}

\subsection{Daily Biogas Production}

Figure 2 showed that the treatment of $\mathrm{B}$ and $\mathrm{E}$ produced biogas since 2 days of digestion.

\subsection{Total Biogas Production}

As displayed on Table 1, the treatment A did not produced biogas, while the others produced the biogas in the different volume with the order of B (14.183 $\left.\mathrm{cm}^{3}\right), \mathrm{E}\left(7.250 \mathrm{~cm}^{3}\right), \mathrm{D}\left(2.400 \mathrm{~cm}^{3}\right)$ and $\mathrm{C}\left(895 \mathrm{~cm}^{3}\right)$.

\section{3. pH Monitoring}

Figure 3 showed that the $\mathrm{pH}$ fluctuation $\mathrm{did}$ not dramatically change, i.e., 6.4-7.2.

\subsection{Water Boiling}

As shown on Table 2, the time needed to boil 100 $\mathrm{mL}$ of water on the treatments of B, C, D and E were not statistically different.

Table 1. The effect of agricultural waste on the produc-tion of biogas from TLW

\begin{tabular}{ll}
\hline Treatment & Biogas production $\left(\mathrm{cm}^{3}\right)$ \\
\hline A (TLW alone) & $0 \mathrm{a}$ \\
B (TLW+sheep dung) & $14.183 \mathrm{~b}$ \\
C (TLW+paddy straw) & $895 \mathrm{c}$ \\
D (TLW+bamboo litter) & $2.400 \mathrm{~d}$ \\
E (TLW+ abbage waste) & $7.250 \mathrm{e}$ \\
\hline
\end{tabular}

Information: Numbers followed by the same letter indicates not significantly different according to Duncan's Multiple range test level of $5 \%$

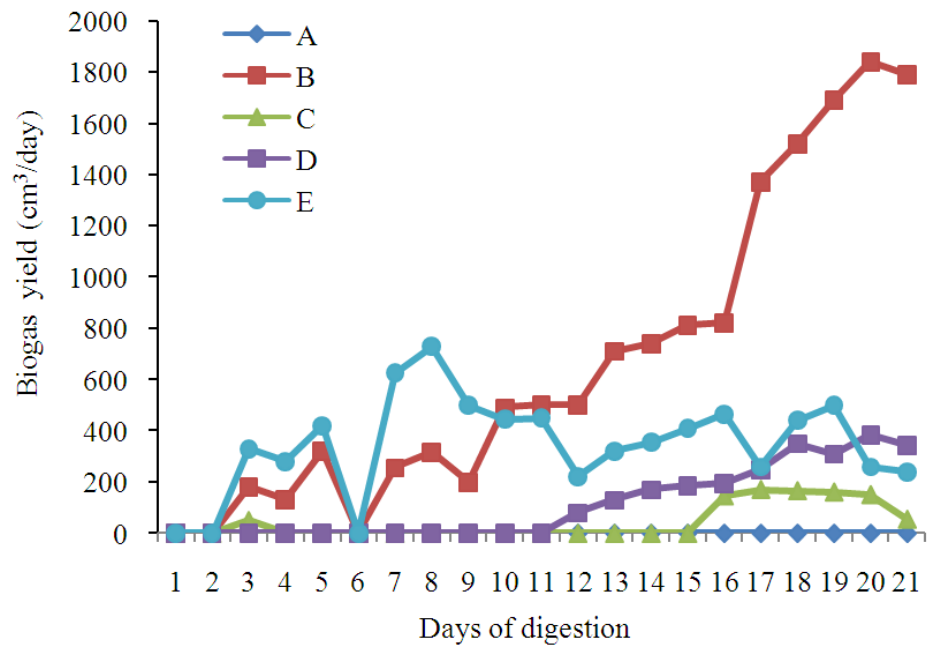

Fig. 2. Daily biogas production from Digester A, B, C, D and E

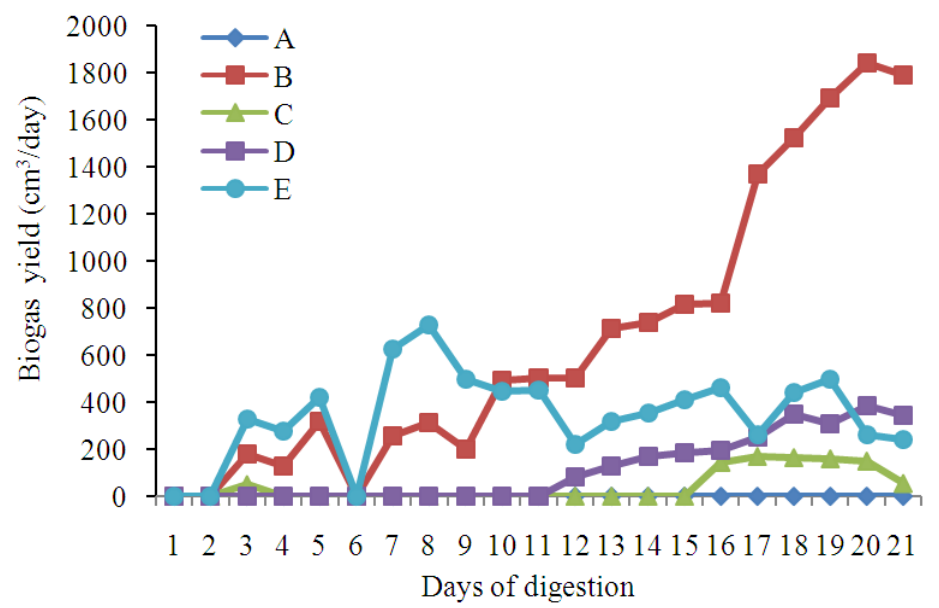

Fig. 3. pH fluctuation 
Table 2. Effect of the treatments on water boiling time

\begin{tabular}{ll} 
Treatment & Water boiling time (min) \\
\hline A (TLW alone) & - \\
B (TLW+sheep dung) & $481 \mathrm{a}$ \\
C (TLW+paddy straw) & $479 \mathrm{a}$ \\
D (TLW+bamboo leaf litter) & $485 \mathrm{a}$ \\
E (TLW+cabbage waste) & $478 \mathrm{a}$ \\
\hline
\end{tabular}

Information: Numbers followed by the same letter indicates not significantly different according to Duncan's Multiple range test level of $5 \%$

\section{DISCUSSION}

\subsection{Biogas Production}

The daily biogas production on the treatment $\mathrm{B}$ continuously increased until $2000 \mathrm{~cm}^{3} /$ day on the 20 th day. On the treatment $\mathrm{E}$, the production was relatively constant, 200-600 $\mathrm{cm}^{3} /$ day. This indicated that those treatments had potential to produce the biogas in 20 days. On the treatment $\mathrm{C}$, the biogas commenced to be produced after the 15 th day since it has the complex component. Therefore it took a longer time to digest. The previous research by Patil et al. (2011) showed that poultry litter produced the highest biogas with better rate as it contains more nutrients compared to primary sludge and water hyacinth.

The plot of observation time (day) and the increase of biogas pressure $\left(\mathrm{N} / \mathrm{m}^{2}\right)$ or the biogas volume $\left(\mathrm{cm}^{3}\right)$ had the parabola pattern. The increase of relative pressure on the biogas productivity reached the peak on the $\mathrm{n}^{\text {th }}$ day. Then, the relative productivity decreased as the biomass was degraded into biogas by anaerobic bacteria during the degradation process (Goendi et al., 2008).

The biogas production was determined by several important factors, such as the $\mathrm{C} / \mathrm{N}$ ratio of the substrate. The sheep dung might be able to increase the ratio from 5 to 15 . This condition was better from the methanogen bacteria to produce higher amount of biogas. Besides, when the TSS value was low, it should be changed to fulfill the minimum requirements of the methanogen bacteria on the liquid waste. This would be affect the amount of biogas produced during the anaerobic degradation (Suyitno and Dharmanto, 2010).

The TLW (treatment A), itself, could not produce the biogas as it was not suitable for the methanogen bacteria. The previous research by Goendi et al. (2008) showed that the TLW had low TSS. The low TSS affected the produced biogas. Therefore, the difference on the biogas production on this research depended on the characteristics of the organic materials. Budiyono et al. (2011) mentioned that the best performance for biogas production was the digester with 7.4 and $9.2 \%$ of TSS

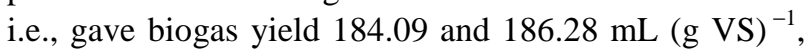
respectively after 90 days observation. While the other TSS content of 2.6, 4.6, 6.2, 12.3 and $18.4 \%$ gave the biogas yield 115.78, 122.33, 172.34, 137.99 and 54.87 $\mathrm{mL}\left(\mathrm{gVS}^{-1}\right.$, respectively.

The reductions in total solids, total suspended solids, fixed suspended solids, total Kjeldahl nitrogen, ammonium nitrogen and methane yield were all significantly affected by the diurnal temperature range and hydraulic retention time (Ghaly and Al Hattab, 2011).

The efficiency of anaerobic digestion depended on the intensity of bacteria activity, which was affected by several factors of temperature of the environment, the temperature of digester material, loading rate, retention time, the $\mathrm{pH}$ value of digester. Hence, all the factors should be set to give the efficient performance. The biogas production depended also on the temperature of environment of certain area (Suyitno and Dharmanto, 2010; Adnan, 2010).

The inorganic solid on the bottom of vessel were stone, sand, gravel or non-degradable material. The waste was the remaining semisolid material after the gas separation. The waste containing the fiber material was difficult to digest and will be floated above the supernatant. The material consisted of the plants. The flammable gas mixture will rise to the top of the tank (Adnan, 2010).

\section{2. pH Fluctuation}

pH fluctuation did not dramatically change, i.e., 6.47.2. The value was on the optimum $\mathrm{pH}$ for the anaerobic digestion, thus this condition was not the limiting factor in producing the biogas. Budiyono et al. (2011) mentioned there was no variation of $\mathrm{pH}$, fat, protein and ash content in sludge after digestion. During digesting, $\mathrm{pH}$ tends to increase to neutral $\mathrm{pH}$ i.e., optimum $\mathrm{pH}$ for methanogenic bacteria.

The measured reactor $\mathrm{pH}$ followed a diurnally cyclic pattern which was in phase with the reactor temperature. At the operating temperature cycle of $20-40^{\circ} \mathrm{C}$, the reactor $\mathrm{pH}$ ranged from 6.80-7.54 while Volatile Fatty Acid (VFA) concentration ranged from $44.7-154.8 \mathrm{mg} \mathrm{L}^{-1}$. At the operating temperature cycle of $15-25^{\circ} \mathrm{C}$, the $\mathrm{pH}$ ranged from 6.30-6.60 while the VFA concentration ranged from 151.0-1187.0 $\mathrm{mg} \mathrm{L}^{-1}$ (Ghaly and Al Hattab, 2011).

\subsection{Biogas Calorie Value}

The calorie of quality produced by the treatments B, C, D and E was not significantly different. This 
indicated that the quantity of methane was not different. According to Goendi et al. (2008), biogas was gas that could be burned, which was produced from the anaerobic fermentation of organic material such as animal and human dung, agricultural waste biomass, or the mixture of both of them. It was reported that the biogas consisted of $50-80 \%$ of methane and $20-50 \%$ of carbon dioxide. Kaswinarni (2007) stated that the biogas reactor might contain $60-70 \%$ of methane, 30$40 \%$ of carbon dioxide and the other gas such as ammonia, hydrogen sulfide, mercaptane (thioalcohol).

The main components of biogas were methane (54$70 \%)$ and carbon dioxide (27-45\%). The former might be employed as the fuel. The biogas had high calorie value $\left(4,800-6,700 \mathrm{kcal} / \mathrm{m}^{3}\right)$, while the pure methane had 8,900 $\mathrm{kcal} / \mathrm{m}^{3}$ (Azlina and Idris, 2009).

Roati et al. (2012) studies that focused on the evaluation of the theoretical biogas and methane production of some food wastes, coming out from rice, hazelnut and wine processing, on the grounds of their physical-chemical characterization. Almost all of the considered samples exhibited biogas theoretical yields equal to about $0.7-1.6 \mathrm{~m}^{3} /(\mathrm{kg} \mathrm{VS})^{-1}$ and methane contents equal to about $40-60 \% \mathrm{v} / \mathrm{v}$.

Methane was the important component of biogas to be applied as the fuel. The pure methane is colorless and odorless. The spontaneous flame occurred when $4-15 \%$ of gas mixed with the air with the explosion pressure of 90 and 104 psi. The pressure showed that the biogas was flammable and should be carefully handled. The knowledge of this fact was important to plan, design, construct and use a digester (Adnan, 2010).

\section{CONCLUSION}

Tofu liquid waste as the control did not produce the biogas. Tofu liqiud waste combined with sheep dung, cabbage waste, bamboo leaves and paddy straw respectively produced biogas as much as 14,183, 7,250, $2,400,895 \mathrm{~cm}^{3}$ in 20 days.

The 4 treatments (sheep dung, cabbage waste, bamboo leaves and paddy straw) gave the same quality of biogas, which was determined using the water boiling test.

The $\mathrm{pH}$ fluctuation during the process was in the right $\mathrm{pH}$ for anaerobic digestion, thus it was not the limiting factor.

The study only compared the addition treatments of organic material, did yet not examined in detail the chemical interactions that occured. Therefore, it still needed a further investigation on the initial conditions of the substrate and chemical changes that occured in the digester during the process.

\section{ACKNOWLEDGEMENT}

The researcher wish to thank the financial support provided by the DIPA Kopertis IV Directorate General of Higher Education of Ministry Education and Culture Republic Indonesia with under contract number 0901/K4/KL/2013.

\section{REFERENCES}

Adnan, M.A.B., 2010. Design of biogas digester (Indian Type). Thesis Bachelor Mechanical Engineering, University Malaysia, Pahang.

Astuti, A.D., W. Wisaksono and A.R. Nurwini, 2007. Pengolahan Air Limbah Tahu Menggunakan Biorektor Anaerob-anaerob Bermedia Karbon Aktif dengan Variasi Waktu Tunggal. J. Puslit Petra, 4: 31-35.

Azlina, A.G. and A. Idris, 2009. Preliminary study on biogas production from Municipal Solid Waste (MSW) leachate. J. Eng. Sci. Technol., 4: 374-380.

Budiyono, I.N. Widiasa, S. Johari and Sunarso, 2011. The influence of total solid contents on biogas yield from cattle manure using rumen fluid inoculum. Energy Res. J., 1: 6-11. DOI: 10.3844/erjsp.2010.6.11

Burke, D.A.P.E., 2001. Dairy Waste Anaerobic Digestion Handbook. Environmental Energy Company.

Ghaly, A.E. and M.T. Al Hattab, 2011. Effect of diurnally cyclic temperature on the performance of a continuous mix anaerobic digester. Am. J. Biochem. Biotechnol., 7: 146-162. DOI: 10.3844/ajbbsp.2011.146.162

Goendi, S., T. Purwadi and A.P. Nugroho, 2008. Kajian model digester limbah cair tahu untuk produksi biogas berdasarkan waktu penguraian. Proceedings of the Seminar Nasional Teknik Pertanian, Nov. 1819, Yogyakarta, pp: 1-11.

Gomez, K.A. and A.A. Gomez, 1984. Statistical Procedures for Agricultural Research. 2nd Edn., John Wiley and Sons, New York, ISBN-10: 0471879312, pp: 680.

Husni, H. and E. Esmiralda, 2012. Uji toksisitas akut limbah cair tahu industri tahu terhadap ikan mas (Cyprinus carpio Lin). Universitas Andalas.

Kaswinarni, F., 2007. Kajian Teknis pengolahan limbah padat dan cair industri tahu. MSc. Thesis, Program Pasca Sarjana, Universitas Diponegoro. 
Novita, F.D., 2009. Pengaruh frekuensi dan konsentrasi penyiraman air limbah pembuatan tahu terhadap pembuatan tahu terhadap pertumbuhan tanaman sawi. Skripsi Sarjana Jurusan Biologi Fakultas Sains dan Teknologi Universitas Negeri Malang.

Patil, J.H., M.A.L. Antony Raj and C.C. Gavimath, 2011. Study on effect of pretreatment methods on biomethanation of water hyacinth. Int. J. Adv. Biotechnol. Res., 2: 143-147.
Roati, C., S. Fiore, B. Ruffino, F. Marchese and D. Novarino et al., 2012. Preliminary evaluation of the potential biogas production of food-processing industrial wastes. Am. J. Environ. Sci., 8: 291-296. DOI: 10.3844/ajessp.2012.291.296

Suyitno, M. and N. Dharmanto, 2010. Teknologi Biogas. 1st Edn., Graha Ilmu, Yogyakarta. 